\title{
The Impact of Cross-Shareholding Networks on Financing Constraints --Empirical Data from Manufacturing Companies
}

\author{
Qing Xia, Hua Li", Qiubai Sun \\ School of Business Administration, University of Science and Technology Liaoning, Anshan, China \\ *Corresponding Author.
}

\begin{abstract}
As the financial markets have evolved, the cross-shareholding networks have been formed among Chinese enterprises with equity as the concluded relationship. Exploring the impact of the cross-shareholding networks on financing constraints has important implications for the decisions of manufacturing companies. This paper uses the social network method to characterize the cross-shareholding networks of manufacturing companies from 2007 to 2019 and explores the effects of the cross-shareholding networks on financing constraints. The innovation of this paper is to explore the relationship between the two. It is concluded that the centrality or structural holes richness of manufacturing companies in the cross-shareholding network is inversely related to the financing constraint. The higher the centrality or the richer the number of structural holes, the lower the level of financing constraints.
\end{abstract}

Keywords: Cross-shareholding, social networks, financing constraints, manufacturing companies

\section{Introduction}

With the globalization of the economy and the booming development of the Internet, China's financial market has also been enhanced at a high speed. Due to the frequent exchange of information between companies, different networks have been concluded between them. Some of the listed companies in China hold shares of each other, and the equity connection relationship between enterprises makes them form a cross-shareholding network. The cross-shareholding in a narrow sense refers to the shareholding between two enterprises holding each other's shares, with the number of cross-shareholding in China gradually increasing, the current cross-shareholding refers to the linear, circular or network cross-shareholding formed between enterprises through one-way shareholding relationship or two-way shareholding relationship. Economic development is a prerequisite for a country to flourish, and for the future economic development of China, the financing constraints problem will act as a bottleneck that limits the innovative growth of companies, and how to solve this problem is also the focus of scholars' attention at present.

Currently, few scholars have explored the impact of the unique cross-shareholding networks formed among firms on the financing constraints. Based on previous studies, this paper chooses degree centrality and Constraint to explore the impact of cross-shareholding network of listed companies on financing constraints.

\section{Literature review and research hypothesis}

\subsection{Literature review}

\subsubsection{Review of foreign related literature}

Cross-shareholding originated in Japan, and the purpose of the earliest cross-shareholding was to prevent a hostile takeover. When cross-shareholdings first began to prevail among foreign firms, Williamson found that the primary motivation for cross-shareholdings among early firms was to hedge the firm's transaction risk [1]. Morck and Nakamura, using Japanese firms with cross-shareholding relationships as the subject of their study confirmed that cross-shareholdings do have an important role in preventing hostile takeovers [2]. Since the emergence of the concept of social networks in the 1970s, many scholars have applied social network methods to various disciplines, with frequent applications in the field of economics and management. Burt introduced the concept of structural holes and showed that actors in social networks are able to integrate their own information and resources, and pointed out

ISSN: 0010-8189

(C) CONVERTER 2020 
that structural holes have a very important role in social networks [3]. The financing constraint is a situation in which companies prefer to use internal funds for their investment activities because of the high cost of external financing due to the imperfect market in practice, thus preventing them from making optimal decisions in the investment process. Jensen and Meckling suggested that when the ownership of a company is separated from its operation, there is an agency conflict when management makes decisions that are detrimental or even detrimental to the long-term development of the firm [4]. Mark states that the main reasons for the high cost of external financing due to market incompleteness are agency problems and information asymmetry [5].

\subsubsection{Review of domestic related literature}

Compared with foreign studies, the research related to cross-shareholding in China started late. Chu and Wang analyzed the motivation of the first cross-shareholding case in China and showed that Liaoning Chengda and Guangfa Securities were motivated to conduct cross-shareholding to obtain higher investment returns by integrating the superior resources between them [6]. In recent years, scholars in China have begun to conduct relevant research on cross-shareholding networks. Sha et al. explored the effect of cross-shareholding networks on firm performance and showed a positive relationship between centrality and structural hole richness and firm performance [7]. Song et al. found that in cross-shareholding networks, the higher the centrality of a firm's location or the greater the number of structural holes it occupies, the more it reduces the risk taken by the firm [8]. The issue of financing constraints has been the focus of attention of domestic scholars. Jiang et al. found that companies with multiple large shareholders are effective in reducing the level of financing constraints [9]. Wu et al. divided the functional configuration of finance companies and concluded that loan and guarantee functions are the most effective in alleviating the financing constraint problem [10]. Yu et al. found that private companies are usually more prone to financing constraints than state-owned companies, which can inhibit the growth of firms [11].

In summary, the cross-shareholding networks will enhance the information exchange between firms. This paper uses cross-shareholding data as a sample to explore the connection of the cross-shareholding networks and financing constraints.

\subsection{Research hypothesis}

It has been shown that the access to resources and information varies depending on the location of the firm in the social network. In imperfect capital markets, financing constraints exist mainly because of information asymmetry and agency problems [12-13]. And the location of enterprises in social networks will alleviate such problems.

Centrality is the main indicator used by scholars to study companies through the social network approach. When the centrality of a company in the social network is higher, the more central the company is in the social network. When the centrality of a company in the social network is lower, the more peripheral the company is in the social network. When a firm is more centrally located in a cross-shareholding network, the more connections it has with other firms. This will form long-term and stable cooperative relationships and access to more information resources, thus reducing the cost of the enterprise, reducing the financing constraint problem of the enterprise. Hypothesis 1 is proposed:

H1 When the centrality of the firm in the cross-shareholding network is higher, the firm will face a lower financing constraint problem.

The concept of structural holes was introduced by Burt in 1992, who pointed out that "there are certain actors in a social network that are not directly connected to each other. A structural hole represents a non-redundant connection between two actors, and a third party who connects the two without direct connection will have an information advantage and control advantage." In a cross-shareholding network, not all companies are connected to each other in a cross-shareholding relationship. In this way, when an enterprise has more structural holes in a social network, it becomes a "bridge" for communication between other members, and its important position facilitates its control of information and resources, so as to reduce its own financing constraints [14]. Therefore, Hypothesis 2 is proposed: $\mathrm{H} 2$ The greater the number of structural holes occupied by the firm, the lower the financing constraints the firm will

ISSN: 0010-8189

(C) CONVERTER 2020

www.converter-magazine.info 
face.

\section{Research Design}

\subsection{Data sources}

The cross-shareholding data are obtained from the WIND database. The data in this paper are selected from a sample of listed companies involved in cross-shareholding in China's Shanghai and Shenzhen A-shares from 2007-2019, and the cross-shareholding network data are analyzed using UCINET software. In the multiple regression analysis, the samples are screened according to the following conditions: (1) exclude ST and *ST samples (2) exclude financial industry samples (3) exclude samples listed in IPO in the current year (4) exclude samples with missing data, and the paper winsorize at the $1 \%$ level for the main continuous variables to finally obtain 9086 observations. The financial data are obtained from the CSMAR database.

\subsection{Variable selection and definition}

\subsubsection{Financing constraints}

The current indicators used by scholars to measure financing constraints are the KZ index [15] and the WW index [16]. The above three indexes need to be measured using internal information of enterprises, and in order to prevent endogeneity problems when measuring financing constraints, this paper draws on the studies of Hadlock and Pierce and Ju et al [17-18], and selects the SA index to measure the corporate financing constraints and the WW index for robustness test. The formula is as follows:

$$
\mathrm{SA}_{\mathrm{i}, \mathrm{t}}=-0.737 * \mathrm{Size}_{\mathrm{i}, \mathrm{t}}+0.043 * \mathrm{Size}_{\mathrm{i}, \mathrm{t}}^{2}-0.04 * \mathrm{Age}_{\mathrm{i}, \mathrm{t}}
$$

There, Size $=($ total assets of the firm / 1000000), Age is the company's listing year. In this paper, the SA index is taken as absolute value, and the higher its value indicates the higher degree of financing constraint to which the company is subjected (Ju et al., 2013).

\subsubsection{Network location indicators}

\section{(1) Degree centrality}

In this paper mainly measures the number of relationships that firms have through cross-shareholdings with other firms, so degree centrality is chosen to measure the centrality of a company [19]. It is used to measure the most dominant central figure in the group. The main measure is the size of the number of nodes connected to that node. Its formula is:

$$
\text { Ndegree }=\frac{\sum \mathrm{a}_{\mathrm{ij}}}{\mathrm{g}-1}
$$

aij takes the value of 0 or 1 , representing whether actor $\mathrm{j}$ acknowledges a relationship with actor $\mathrm{i}$, and $\mathrm{g}$ is the number of people in this network. It is divided by ( $\mathrm{g}-1)$ to eliminate the size difference.

\section{(2) Structural hole}

In this paper, the Constraint is chosen to measure the structural hole richness. Meanwhile, since the maximum value of Constraint is 1, many scholars use the difference between 1 and Constraint to portray the richness of structural holes occupied by network members for the sake of convenience [20]. The larger the difference value is, the richer the number of structural holes of the firm.

$$
\text { Constra }=1-\sum_{j}\left(P_{i j}+\sum_{q} P_{i q} P_{q j}\right)^{2}
$$

where $\mathrm{i}$ denotes the focal firm, $\mathrm{j}$ denotes the firms other than the focal firm $\mathrm{i}$, and $\mathrm{q}$ is the other firms other than firms $\mathrm{i}$ and $\mathrm{j}$. Pij denotes the direct constraint of firm $\mathrm{j}$ on firm $\mathrm{i} . \sum_{\mathrm{q}}^{\mathrm{P}_{\mathrm{iq}} \mathrm{P}_{\mathrm{qj}}}$ is equivalent to the sum of the strength of the indirect ties in all paths from $\mathrm{i}$ to $\mathrm{j}$ through $\mathrm{q}$, and the measure is the investment in indirect ties. A higher degree of constraint indicates that the firm has fewer structural holes, and it effectively measures the degree of scarcity of

ISSN: 0010-8189 
structural holes.

\subsubsection{Control variables}

In this paper, Return on Equity (ROE), Retained Earning (Ret-e),Operating Cash Flow (Ocf), Shareholding Proportion of the Controlling Shareholder (Cr-1), and Years of Listing (Age) are selected as control variables. Where there is collinear between Age and the SA index, so it is only used when the WW index is used instead of the SA index for robustness check. This paper controls for Industry and Year. The details are shown in Table 1:

Table 1 Variable definitions

\begin{tabular}{|c|c|c|c|}
\hline Type & Name & Symbol & Description \\
\hline $\begin{array}{l}\text { Dependent } \\
\text { variable }\end{array}$ & Financing constraints & SA & Absolute value of SA index \\
\hline \multirow{2}{*}{$\begin{array}{l}\text { Independent } \\
\text { variable }\end{array}$} & Degree centrality & Ndegree & Ndegree $=\frac{\sum \mathrm{a}_{\mathrm{ij}}}{\mathrm{g}-1}$ \\
\hline & Structure holes richness & Constra & Constra $=1-\sum_{\mathrm{j}}\left(\mathrm{P}_{\mathrm{ij}}+\sum_{\mathrm{q}} \mathrm{P}_{\mathrm{iq}} \mathrm{P}_{\mathrm{qj}}\right)^{2}$ \\
\hline \multirow{5}{*}{$\begin{array}{l}\text { Control } \\
\text { Variable }\end{array}$} & Return on Equity & ROE & Net Profit/Equity \\
\hline & Retained Earning & Ret-e & $\begin{array}{l}\text { Retained earnings at end of period/total } \\
\text { assets }\end{array}$ \\
\hline & Operating Cash Flow & Ocf & Net operating cash flow/total assets \\
\hline & $\begin{array}{l}\text { Shareholding proportion of } \\
\text { the controlling shareholder }\end{array}$ & Cr_1 & $\begin{array}{l}\text { Shareholding proportion of the controlling } \\
\text { shareholder/Capitalization }\end{array}$ \\
\hline & Years of listing & Age & Natural logarithm of the listed years \\
\hline
\end{tabular}

\subsection{Construction of the model}

In this paper, we construct the following two models to test hypothesis 1 and hypothesis 2, as follows:

$$
\begin{aligned}
& \mathrm{SA}_{i t}=\alpha_{0}+\alpha_{1} \text { Ndegree }_{i t}+\alpha_{2} \text { Re tit }_{i}+\alpha_{3} \mathrm{Cr}_{-} 1_{i t}+\alpha_{4} \mathrm{Ofc}_{\mathrm{it}}+\alpha_{5} \mathrm{ROE}_{\mathrm{it}}+\sum \text { Year }+\sum \text { Industry }+\varepsilon_{\mathrm{it}}
\end{aligned}
$$

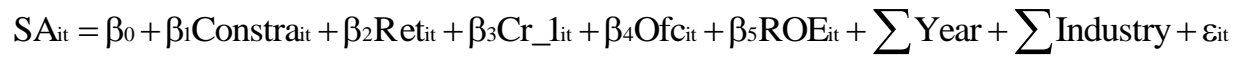

Where SA is the dependent variable, Ndegree and Constra are the independent variables, Ret, Cr_1, Ofc, and ROE are the control variables, Year and Industry are dummy variables, and $\boldsymbol{E}_{\text {it }}$ represents the error term. Hypothesis 1 and Hypothesis 2 hold if the coefficients of $\alpha_{1}$ and $\beta_{1}$ are significantly negative.

\section{Data Analysis and Empirical Results}

\subsection{Analysis of cross-shareholding social network}

As shown in Table 2, the social network of cross-shareholding in 2019 is carved using UCINET software, and the number of listed companies involved in cross-shareholding in 2019 is 724, and the density is 0.0016 , which indicates that the density among listed companies in the cross-shareholding network is low. The unit refers to the existence of certain linking relationship between listed companies, and the listed companies in the unit are not connected with the listed companies in other units, and the number of units is 48 , among which the maximum number of units reaches 594, indicating that 594 of the 724 listed companies have direct or indirect cross-shareholding relationship, which is independent of the other companies' cross-shareholding. The centrality of the group in this network is $7.16 \%$, which indicates that the gap between the companies with the highest degree of centrality and other companies is not large, and there are no companies with more concentrated power.

Table 2 Social network analysis of cross-shareholding networks in 2019

\begin{tabular}{|c|c|}
\hline Name & Value \\
\hline Number of cross-shareholdings & 724 \\
\hline Overall density & 0.0016 \\
\hline Number of units & 48 \\
\hline Maximum number of units & 594 \\
\hline Group degree centrality & $7.16 \%$ \\
\hline
\end{tabular}

ISSN: 0010-8189 
Figure 1 shows the social network diagram of cross-shareholdings of listed companies in 2019.

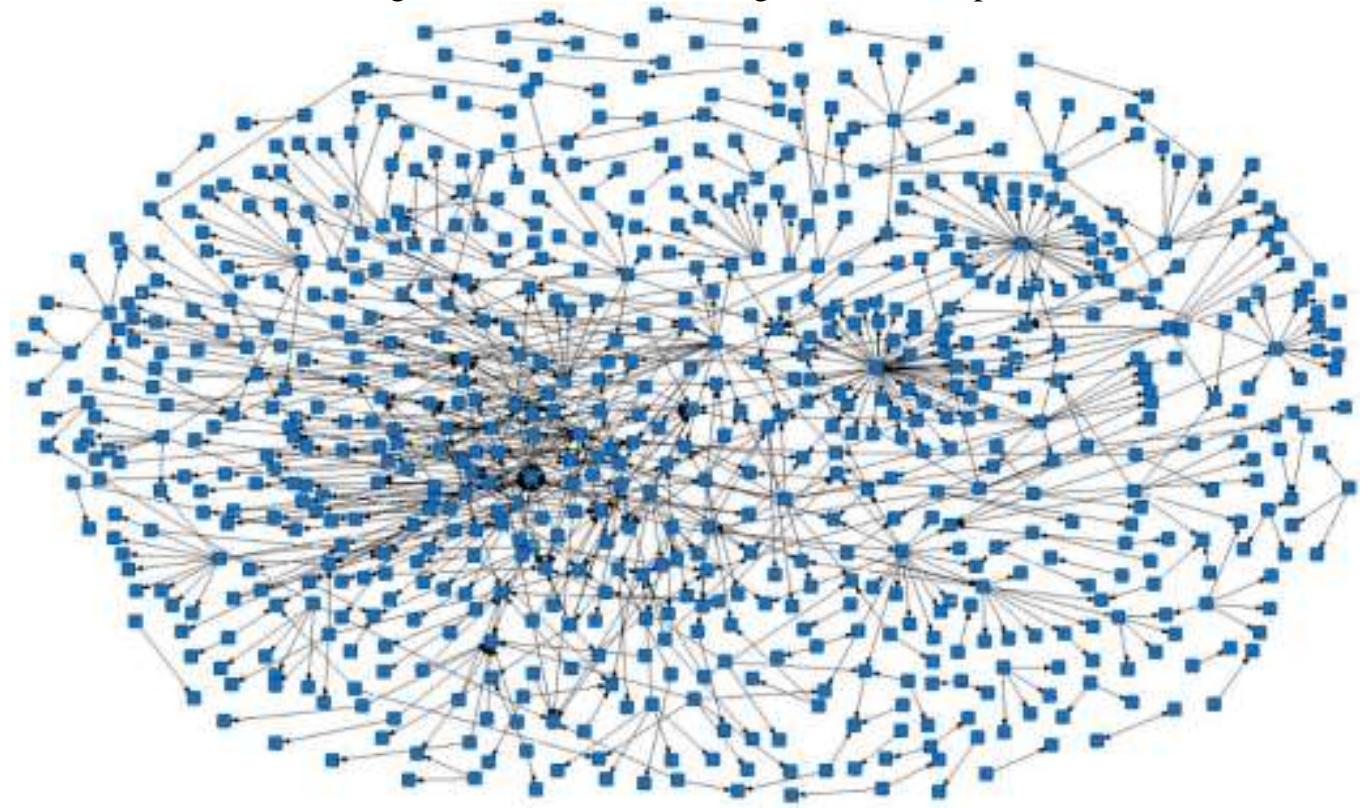

Fig 1: Social network map of cross-shareholdings in 2019

As shown in Figure 1, the cross-shareholding network is a directional social network diagram. The largest number of shareholdings is Kaikai Industrial (600272), which indicates that it has the greatest influence in this network and is at the center of the network, and the other listed companies play a secondary role to this company in this relationship network.

\subsection{Descriptive statistics}

As indicated in Table 3, the maximum value of degree centrality is 2.099 , the minimum value of degree centrality is 0.104. The maximum value of the difference between 1 and Constraint is 0.936 , the minimum value is 0 . There is a big difference between the values. It indicates that listed companies have a large difference in their position. Form the absolute value of SA index, we can see that the listed companies in the cross-shareholding network have financing constraints.

Table 3 Descriptive statistics

\begin{tabular}{|c|c|c|c|c|c|}
\hline Variable & obs & mean & $\max$ & $\min$ & sd \\
\hline SA & 9086 & 3.787 & 4.469 & 2.711 & 0.282 \\
\hline Ndegree & 9086 & 0.325 & 2.099 & 0.104 & 0.370 \\
\hline Constra & 9086 & 0.327 & 0.936 & 0 & 0.353 \\
\hline Ret-e & 9086 & 0.150 & 0.583 & -0.602 & 0.169 \\
\hline Cr_1 & 9086 & 36.31 & 75.05 & 8.790 & 15.70 \\
\hline Ofc & 9086 & 0.0480 & 0.255 & -0.174 & 0.0720 \\
\hline ROE & 9086 & 0.0770 & 0.355 & -0.483 & 0.106 \\
\hline
\end{tabular}

\subsection{Multiple regression analysis}

In Table 4, Model 1 shows the multiple regression results between the dependent variable SA index and the control variables. The results show that ROE, Cr_1 and Ofc are negatively correlated with the SA index, Ret-e is positively correlated with the SA index. Model 2 adds the degree centrality to the control variables. The results show that there is a negative relationship between the degree centrality index and SA index, indicating that the higher the centrality of listed companies, the lower the level of financing constraints they are subject to, so Hypothesis 1 is verified. Model 3 adds structural hole to the control variables, and the results show that there is a negative relationship between structural holes and SA index, indicating that the richer the number of structural holes in the cross-shareholding network of listed companies, the lower the level of financing constraints they suffer from, and Hypothesis 2 is verified.

ISSN: 0010-8189

(C) CONVERTER 2020

www.converter-magazine.info 
Table 4 Regression analysis results

\begin{tabular}{|c|c|c|c|}
\hline \multirow{2}{*}{ Variable } & \multicolumn{3}{|c|}{ Dependent variable (SA Index) } \\
\hline & Model 1 & Model 2 & Model 3 \\
\hline Ndegree & & $-0.048 * * *$ & \\
\hline Constra & & & $-0.024 * * *$ \\
\hline Ret-e & $0.163 * * *$ & $0.167 * * *$ & $0.165^{* * *}$ \\
\hline Cr_1 & $-0.004 * * *$ & $-0.004 * * *$ & $-0.004 * * *$ \\
\hline$\overline{\text { Ofc }}$ & $-0.153 * * *$ & $-0.151 * * *$ & $-0.155 * * *$ \\
\hline ROE & $-0.064 * * *$ & $-0.063 * * *$ & $-0.061 * * *$ \\
\hline Constant & $3.791 * * *$ & $3.805 * * *$ & $3.798 * * *$ \\
\hline $\begin{array}{l}\text { Industry } \\
\text { Year }\end{array}$ & Control & Control & Control \\
\hline R-squared & 0.266 & 0.272 & 0.270 \\
\hline F-value & 266.8 & 134.8 & 179.0 \\
\hline $\mathrm{N}$ & 9,086 & 9,086 & 9,086 \\
\hline
\end{tabular}

\subsection{Robustness test}

To test the stability of the model, the WW index is used to measure the financing constraint. Its formula is as follows:

$$
\mathrm{WW}_{\mathrm{it}}=-0.062 \times \mathrm{DIVPOS}_{\mathrm{it}}-0.091 \times \mathrm{CF}_{\mathrm{it}}-0.044 \times \mathrm{LNTA}_{\mathrm{it}}-0.021 \times \mathrm{TLTD}_{\mathrm{it}}-0.035 \times \mathrm{SG}_{\mathrm{i}}+0.102 \times \mathrm{ISG}_{\mathrm{itt}}
$$

In this formula, DIVPOS is a dummy variable to determine whether or not to pay dividends, taking the value of 0 or 1. $\mathrm{CF}=$ operating cash flow/ total assets. LNTA is the natural logarithm of total assets. TLTD $=$ total liabilities/ total assets. SG is sales growth rate and ISG is industry sales growth rate.

As shown in Table 5, the stability test uses the WW index instead of the SA index to measure financing constraints lever and adds the Age control variable, and its empirical results are consistent with the previous, which verifies Hypotheses 1 and 2.

Table 5 Robustness test results

\begin{tabular}{|c|c|c|c|}
\hline \multirow{2}{*}{ Variable } & \multicolumn{3}{|c|}{ Dependent variable (WW Index) } \\
\hline & Model 4 & Model 5 & Model 6 \\
\hline Ndegree & & $-0.037 * * *$ & \\
\hline Constra & & & $-0.037 * * *$ \\
\hline Age & 0.003 & $0.006 * * *$ & $0.007 * * *$ \\
\hline Cr_1 & $-0.001 * * *$ & $-0.001 * * *$ & $-0.001 * * *$ \\
\hline Ofc & $-0.086 * *$ & $-0.084 * *$ & $-0.088 * *$ \\
\hline ROE & $-0.222 * * *$ & $-0.219 * * *$ & $-0.215 * * *$ \\
\hline Constant & $-0.948 * * *$ & $-0.943 * * *$ & $-0.904 * * *$ \\
\hline $\begin{array}{c}\text { Industry } \\
\text { Year }\end{array}$ & Control & Control & Control \\
\hline R-squared & 0.201 & 0.205 & 0.201 \\
\hline F-value & 46.33 & 48.11 & 48.55 \\
\hline $\mathrm{N}$ & 8639 & 8639 & 8639 \\
\hline
\end{tabular}

\section{Conclusion}

The effect of cross-shareholding networks on financing constraints is explored in this paper from both centrality and structural vulnerability perspectives. Research shows that listed companies can effectively alleviate the financing constraint problem through cross-shareholding, and the effect is more pronounced when the centrality of companies in the cross-shareholding network is higher or the number of structural holes is richer. The more resources and information obtained, the better it is for enterprises to make corresponding decisions and promote the development of

ISSN: 0010-8189

(C) CONVERTER 2020 
enterprises. Therefore, companies can increase their access to information by establishing cross-shareholding relationships, thus alleviating the financing constraint problem.

In this paper, only centrality and structural holes are selected to measure the cross-shareholding networks. In future research, the author will select other indicators of social networks to explore the relationship between the cross-shareholding networks and financing constraints.

\section{Acknowledgements}

This work was supported by the Innovative Talents Project of Liaoning Province (WCR2018003), Natural Science Foundation of China (71771112, 71571091),Natural Science Foundation of Liaoning Province of China (20180550274), Project of Liaoning Provincial Federation Social Science Circles of China(L20BGL047), University of Science and Technology Liaoning Talent Project Grants (601011507-03), and Soft Science Project of Department of Science \&Technology of Liaoning Province of China(2020JH4/10100008)

\section{References}

[1] O.E. Williamson, "Transaction-Cost Economics: The Governance of Contractual Relations," Journal of Law \& Economics, vol.22, no.2, pp.233-261, 1979.

[2] R. Morck, M. Nakamura, "Banks and Corporate Control in Japan," The Journal of Finance, vol. 54, no. 1, pp. 319-339, 1999.

[3] R.S. Burt, "Structural holes: the social structure of competition," Cambridge: Harvard University Press, pp. 7-91, 1992.

[4] M.C. Jensen, W.H. Meckling, "Theory of the Firm: Managerial Behavior, Agency Costs and Ownership Structure," Springer Netherlands, pp. 305-360, 1979.

[5] G. Mark, "Financial Capacity and Output Fluctuations in an Economy with Multi-Period Financial Relationships," The Review of Economic, vol.59, no.3, pp.541-572, 1992.

[6] Y.Y. Chu, W.Z. Wang, "The Consideration Aroused by China's First Case of Mutual Holding," Management World, no.5, pp.173-186,2001.

[7] H.W. Sha, Y. Zeng, "An Empirical Study on the Cross-shareholding, Network Location and Firm Performance,” Journal of Management Science, no. 1, pp. 133-144, 2014.

[8] P. Song, L.L. Tian, C.H. Li, "Cross-shareholding Network and Corporate Risk-taking,” On Economic Problems, no. 6, pp. 83-89, 2019.

[9] F.X. Jiang, Y.T. Wang, Y. Tian, et al., "Multiple Large Shareholders and Corporate Financing Constraints - Empirical Evidence Based on Text Analysis," Management World, no. 12, pp. 61-74, 2017.

[10] Q.S. Wu, X.H. Huang, "The Function Display of Finance Company and Financing Constraints Relieve of the Group's Listed Companies," China Industrial Economics, no. 09, pp. 158-175, 2017.

[11] M.G. Yu, H.J. Zhong, R. Fan, "Privatization, Financial Constraints, and Corporate Innovation: Evidence from China's Industrial Enterprises," Journal of Financial Research, no.04, pp.75-91,2 019.

[12] S.C. Myers N. S. Majluf, "Corporate Financing and Investment Decisions When Firms Have Information That Investors Do Not Have,” NBER Working Papers, vol. 13, no. 2, pp. 187-221, 1984.

[13] B.M. Gertler, "Agency Costs, Net Worth, and Business Fluctuations," The American Economic Review, vol. 79, no. 1, pp. 14-31, 1989.

[14] Y.S. Chen, "Director's 'Structural Hole' Position and Firm's Policy Efficiency," Accounting Research, no. 1, pp. 48-55, 2015.

[15] S.N. Kaplan, L. Zingales, "Do Investment-Cash Flow Sensitivities Provide Useful Measures of Financing Constraints?" Quarterly Journal of Economics, vol. 112, no. 1, pp. 169-215, 1997.

[16] T.M. Whited, G. Wu, "Financial Constraints Risk," Rev. Financ. Stud, vol. 19, no. 2, pp. 531-559, 2006.

[17] C.J. Hadlock, J.R. Pierce, "New Evidence on Measuring Financial Constraints: Moving Beyond the KZ Index," Review of Financial Studies, vol. 23, no. 5, pp. 1909-1940, 2010.

ISSN: 0010-8189 
[18] X.S. Ju, L. Dic, Y.H. Yu. "Financing Constraints, Working Capital Management and the Persistence of Firm Innovation,” Economic Research Journal, no. 1, pp. 4-16, 2013.

[19] J.D. Luo, "Social Network Analysis," BeiJing: Social Sciences Academic Press (China), pp. 187-198, 2010.

[20] A. Zaheer, G.G. Bell, "Benefiting from network position: firm capabilities, structural holes, and performance,” Strategic Management Journal, vol. 26, no. 9, pp. 809-825, 2005. 